\title{
UJI POTENSI DAUN BABADOTAN (Ageratum conyzoides L.) SEBAGAI INSEKTISIDA BOTANI TERHADAP HAMA (Plutella xylostella L.) DI LABORATORIUM
}

\author{
Nurhudiman, Rosma Hasibuan, Agus M. Hariri \& Purnomo \\ Jurusan Agroteknologi, Fakultas Pertanian, Universitas Lampung \\ J1. Prof. Soemantri Brojonegoro, No. 1 Bandar Lampung 35145 \\ Email: agrohobrintek@yahoo.com
}

\begin{abstract}
Diamond back moth (Plutella xylostella) [Lepidoptera: Plutellalidae] is the most important pest of Brasisca vegetable in many part of area in Indonesia. Pest control of this pest has been relied on the use of synthetic insecticide. However prolog use of insecticide cause ecological and economical problems. There is a need for pest control that are sustainable and eviromentally sound. The use of natural (botanical insecticide) such as Ageratum conyzoides is expected to solve that problem. The objective of this research was to test the capability of goatweed suspension to cause mortality P. xylostella larvae and to measure toxicity level (LC50 and LT50) of Ageratum extract. This research was conduched during Juli 2016- February 2017 in green house and laboratory. The results indicated that all of concentration of goatweed (1-5\%) was able to cause mortality on P. xylostella larvae. The lethal concentration for 50\% mortality (LC50) value was 2,0254\%. While the time need to kill $50 \%$ of P. xylostella larva were: 33.31 h, 20.68 h, 21.09 h, 12.65 h, 10.86 h treated by concentration of: 1\%, 2\%, 3\%, 4\% and 5\% respectively. This study indicated the potential use of Ageratum extract to contol P. xylostella.
\end{abstract}

Kata kunci: Ageratum extract, mortality, Plutella xylostella

\section{PENDAHULUAN}

Kubis merupakan tanaman sayuran yang banyak dibudidayakan oleh petani di Indonesia. Tanaman kubis juga banyak dibudidayakan di Provinsi Lampung antara lain di daerah Gisting Kabupaten Tanggamus. Tanaman kubis yang dibudidayakan dengan baik mampu menghasilkan 30-40 ton/ha. Namun untuk menghasilkan produksi maksimal ada kendala yang dihadapi seperti serangan hama ulat kubis (Plutella xylostella). Di Malaysia apabila tidak menggunakan insektisida, hama dapat menyebabkan kehilangan hasil $87,5 \%$, sedangkan di Indonesia kehilangan hasil bisa mencapai 100\% (Cahyono, 1995).

Pengendalian utama $P$. xylostella pada tanaman kubis adalah dengan insektisida. Namun penggunaan insektisida secara berlebihan dapat memunculkan masalah baru seperti keracunan pada manusia, pencemaran lingkungan, resistensi, resurjensi, dan terbunuhnya organisme bukan sasaran (Untung, 1993) dalam (Andi, 2007). Dari sisi ekonomi hal itu berdampak kerugian seperti yang terjadi di daerah Bandung 30\% dari total biaya produksi adalah penggunaan insektisida (Woodfort, dkk. 1981) dalam (Sastrosiswojo, 2005).

Salah satu upaya untuk menanggulangi hal di atas adalah pengendalian dengan menggunakan bahan alam seperti penggunaan babadotan (Ageratum conyzoides L.) sebagai insektisida botani (Tenrirawe, 2011). Tumbuhan $A$. conyzoides memiliki nama umum babadotan, bandotan, jukut bau atau wedusan (goatweed). Babadotan (A. conyzoides) memiliki kandungan bahan aktif terutama di bagian daun adalah alkaloid, saponin, flavanoid, polifenol, sulfur dan tannin. Bagian daun mempunyai sifat bioaktivitas sebagai insektisida, antinematoda, antibakteri dan alelopati (Grainge dan Ahmed, 1988).

Bahan aktif pada insektisida botani tersebut mampu menyebabkan gangguan aktivitas makan dengan mengurangi nafsu makan, memblokir kemampuan makan serangga sehingga hama menolak makan (Astriani, 2010). Bahan aktif babadotan juga mampu mengganggu peletakan telur, merusak perkembangan telur, serta mampu menghambat reproduksi serangga betina. Kandungan bahan aktifnya terutama saponin mampu memberikan daya repelensi lebih besar dan mampu menghambat pertumbuhan larva menjadi pupa (Samsudin, 2008 ; Grainge dan Ahmed, 1988).

\section{BAHAN DAN METODE}

Tempat dan Waktu. Penelitian ini dilaksanakan pada bulan Juli 2016 - Februari 2017 bertempat di 
Laboratorium Bioteknologi dan Laboratorium Hama Tanaman Fakultas Pertanian Universitas Lampung.

Bahan dan Alat. Bahan yang digunakan yaitu daun babadotan (Ageratum conyzoides), detergen, daun kubis, ethanol, air, madu dan Plutella xylostella, . Alat yang digunakan yaitu toples, strimin, pipet ukur, timbangan, blender, ember, magnetik stirrer, rotary evaporator, gelas Erlemenyer 2 L, corong, dan kertas saring

Metode Penelitian. Percobaan ini disusun dalam Rancangan Acak Kelompok, yang terdiri dari 6 perlakuan dan 3 ulangan. Pada percobaan ini berupa perlakuan konsentrasi dau babadotan terdiri atas 6 konsentrasi: $\mathrm{C}_{0}(0 \%), \mathrm{C}_{1}(1 \%), \mathrm{C}_{2}(2 \%), \mathrm{C}_{3}(3 \%), \mathrm{C}_{4}(4 \%)$ dan $\mathrm{C}_{5}(5 \%)$. Setiap satuan percobaan menggunakan 10 ekor Plutella xylostella instar muda. Homogenitas ragam antar perlakuan diuji dengan Uji Bartlett. Jika asumsi terpenuhi dilakukan uji sidik ragam dan analisis probit. Untuk menentukan nilai toksisitas dan mengetahui pengaruh perlakuan semua data analisis menggunakan perangkat program SAS (9.1.3 SP4).

Pengumpulan Larva (Plutella xylostella). Larva Plutella xylostella diambil dari lahan pertanaman kubis di daerah Gisting Kabupaten Tanggamus. Setelah dapat larva dipisahkan berdasarkan ukuran (Instar) dan dipelihara di dalam toples plastik dengan diberi makan daun kubis. Larva berbentuk silindris, berwarna hijau muda, relatif tidak berbulu dan mempunyai lima pasang proleg (Sastrosiswojo dkk., 2005). Setelah beberapa hari larva menjadi pupa. Antara Larva instar IV sampai prapupa tidak ada pergantian kulit. Pupa dijaga dan ditunggu sekitar 2-3 hari sampai menjadi imago. Selanjutnya imago dipelihara dengan memberikan makanan madu $10 \%$ melalui tisu. Imago akan melakukan perkawinan dan imago betina akan menghasilkan telur. Telur yang dihasilkan dalam waktu 2-3 hari akan menetas menjadi larva.

Perbanyakan Serangga Uji. Larva yang telah menetas dikembangbiakan sampai siap untuk dilakukan pengujian. Larva stadia muda yaitu stadia II dan III paling baik untuk di lakukan pengujian penelitian. Pada instar ini larva memiliki kemampuan bergerak aktif dan memiliki kemampuan beradaptasi yang lebih baik dibandingkan pada larva instar lainya.

Pembuatan Ekstrak Daun Babadotan (Ageratum conyzoides L.). Daun babadotan (Ageratum conyzoides L.) diambil dari lahan lalu dibersihkan dan dikeringkan selama satu minggu. Daun babadotan dihancurkan dengan blender sampai halus. Serbuk halus daun babadotan sebanyak 100 gram dan 1 gram detergen ditambahkan dengan ethanol sampai 1000 $\mathrm{ml}$ lalu diaduk didalam erlemnyer $2 \mathrm{~L}$ menggunakan alat magnetik stirrer selama 1 jam. Ekstrak disaring menggunakan corong yang dialasi kertas saring, kemudian ampas ditambahkan ethanol sampai $1000 \mathrm{ml}$ dan disaring kembali. Kemudian hasil ekstrak pertama disatukan dengan ekstrak kedua selanjutnya dilakukan penguapan melalui rotary evaporator pada suhu $45^{\circ} \mathrm{C}$ $50^{\circ} \mathrm{C}$ dengan kecepatan putaran $100 \mathrm{rpm}$.

Setelah mendapat saringan ekstrak babadotan di angin-anginkan dan setelah kering dikerik sehingga menjadi pasta yang siap digunakan. Untuk mendapatkan konsentrasi $1 \%$ padatan 10 gram babadotan ditambahkan air sampai dengan $1000 \mathrm{ml}$ dan diaduk hingga rata sehingga dapat diaplikasikan. Demikian dikerjakan sampai tersedia konsentrasi $0 \%, 1 \%, 2 \%$, $3 \%, 4 \%$ dan $5 \%$.

Aplikasi Ekstrak Daun Babadotan (Ageratum conyzoides L.). Larva P. xylostella yang ada di dalam toples pemeliharaan tersebut dipindahkan ke toples percobaan berukuran tinggi $10 \mathrm{~cm}$ dan diameter $10 \mathrm{~cm}$. Larva yang dipindahkan adalah larva setelah mencapai stadium instar muda ditandai perubahan berwarna hijau/ coklat pada kepalanya. Pada bagian bawah diletakkan kertas saring pada masing-masing toples berisi 10 ekor serangga uji. Aplikasi dilakukan dengan metode kontak yaitu penyemprotan menggunakan sprayer dengan volume semprot $0,5-1 \mathrm{ml}$.

Pengamatan. Pengamatan dilakukan dengan menghitung persentase larva $P$. xylostella yang mati (mortalitas) dan penghambatan pertumbuhan (serangga cacat). Selain itu perolehan data diamati setiap 1 jam hingga 12 jam selanjutnya setiap 12 jam sekali. Persentase mortalitas larva P. xylostella dapat dihitung menggunakan rumus berikut:

$$
\text { Mortalitas }=\frac{\mathrm{A}}{\mathrm{B}} \times 100 \%
$$

Keterangan :

$\mathrm{A}=$ Jumlah larva $P$. xylostella yang mati

$\mathrm{B}=$ Jumlah larva $P$. Xylostella yang diinfestasi

Selanjutnya dilakukan penghitungan toksisitas ekstrak daun babadotan terhadap P. xylostella dalam nilai Lethal Consentration (LC) dan Lethal Time (LT) dengan analisi probit menggunakan perangkat SAS 9.3. Pengamatan pendukung dilakukan dengan mengamati perilaku hama dan gejala larva $P$. xylostella yang terekspose oleh ekstrak babadotan.

\section{HASIL DAN PEMBAHASAN}

Mortalitas Plutella xylostella. Hasil penelitian membuktikan bahwa babadotan (Ageratum 
conyzoides) memberikan pengaruh nyata terhadap Plutella xylostella setelah diaplikasikan melalui tingkat konsentrasi maupun lamanya waktu. Hasil penelitian menunjukan pengaruh nyata pada perlakuan konsentrasi $1 \%, 2 \%, 3 \%, 4 \%$ dan $5 \%$ sedangakan pada perlakuan kontrol atau konsentrasi $0 \%$ tidak berpengaruh nyata. P. xylostella yang tidak menerima perlakuan dapat hidup normal sampai menjadi imago sedangkan yang menerima perlakuan tidak dapat melaksanakan metamorfosis hingga menjadi imago secara sehat. Keberhasilan suatu insektisida dalam membunuh organisme sangat ditentukan oleh pengaruh takaran konsentrasi yang diberikan (Hasibuan, 2012). Analisis statistik dilakukan pada data mortalitas $P$. xylostella setiap 12 jam (Tabel 1).

Hasil sidik ragam menunjukkan bahwa perlakuan konsentrasi ekstrak daun babadotan berpengaruh nyata pada mortalitas larva $P$. xylostella pada $12,24,36,48$, 60 dan 72 jam setelah aplikasi (jsa) (Tabel 1). Namun pada pengamatan 1 jsa menunjukkan bahwa ektrak babadotan tidak berpengaruh nyata terhadap mortalitas P. xylostella. Selain itu, hasil penelitian menunjukkan bahwa aplikasi daun babadotan (A. conyzoides) dengan berbagai konsentrasi mampu membunuh larva $P$. xylostella (Gambar 1). Daun babadotan pada konsentrasi tertinggi (5\%) dapat menyebabkan kematian P. xylostella sebanyak $46,67 \%$ pada saat 12 jsa dan mencapai $100 \%$ pada saat 72 jsa. Sebaliknnya, pada konsentrasi terendah (1\%) mortalitas P. xylostella adalah $13,33 \%$ pada saat 12 jsa dan mencapai $86,67 \%$ pada saat 72 jsa.

Secara umum, mortalitas $P$. xylostella terus meningkat sejalan dengan waktu pengamatan. Keseluruhan dari 5 taraf konsentrasi yang diuji (1\%, $2 \%, 3 \%, 4 \%$ dan $5 \%$ ) pada setiap 12 jsa pengamatan telah menimbulkan mortalitas serangga uji yang berbeda nyata dengan kontrol (konsentrasi 0\%) Pada pengamatan $12 \mathrm{jsa}$, mortalitas larva $P$. xylostella tertinggi (46,67\%) terjadi pada perlakuan konsentrasi 5\% dan mortalitas larva ini nyata lebih tinggi apabila dibandingkan dengan perlakuan konsentrasi 3\% $(33,33 \%)$, tetapi tidak berbeda nyata dengan perlakuan $4 \%$. Pada saat 72 jsa, persentase mortalitas larva sudah mencapai $100 \%$ pada konsentrasi $5 \%$ sedangkan pada perlakuan $1 \%$ persentase mortalitas $86,67 \%$.

Toksisitas Ekstrak Daun Babadotan terhadap Plutella xylostella. Toksisitas ekstrak daun babadotan dapat ditetapkan dengan menghitung Lethal Concentration pada waktu 24 jsa dengan uji probit menggunakan perangkat SAS. Nilai LC 15 pada 24 jam adalah 0,38673. Dengan kata lain, ekstrak daun babadotan sebesar 0,38673\% akan membunuh larva $15 \%$ ketika 24 jsa. Sedangkan nilai LC 50 adalah 2,02539 dan LC 95 adalah 28,03776. Secara umum nilai LC yang digunakan adalah untuk penentuan daya racun adalah LC 50. Dengan demikian, toksisitas (LC50) menunjukkan bahwa pada konsentrasi $2,02539 \%$ menyebabkan kematian $50 \%$ populasi serangga uji (Tabel 2 ).

Tabel 1. Pengaruh perlakuan konsentrasi ekstrak daun babadotan (A. conyzoides) terhadap mortalitas Plutella xylostella

\begin{tabular}{clllllll}
\hline $\begin{array}{c}\text { Konsentrasi } \\
(\%)\end{array}$ & 1 jsa & 12 jsa & 24 jsa & 36 jsa & 48 jsa & 60 jsa & 72 jsa \\
\hline $0 \%$ & $0,00 \mathrm{a}$ & $0,00 \mathrm{~d}$ & $0,00 \mathrm{e}$ & $0,00 \mathrm{~d}$ & $0,00 \mathrm{~d}$ & $0,00 \mathrm{c}$ & $0,00 \mathrm{~d}$ \\
$1 \%$ & $0,00 \mathrm{a}$ & $13,33 \mathrm{c}$ & $36,67 \mathrm{~d}$ & $50,00 \mathrm{c}$ & $63,33 \mathrm{c}$ & $73,33 \mathrm{~b}$ & $86,67 \mathrm{~b}$ \\
$2 \%$ & $6,67 \mathrm{a}$ & $33,33 \mathrm{~b}$ & $43,33 \mathrm{~cd}$ & $66,67 \mathrm{~b}$ & $73,33 \mathrm{bc}$ & $76,67 \mathrm{ab}$ & $73,33 \mathrm{c}$ \\
$3 \%$ & $0,00 \mathrm{a}$ & $33,33 \mathrm{~b}$ & $56,67 \mathrm{bc}$ & $66,67 \mathrm{~b}$ & $73,33 \mathrm{bc}$ & $80,00 \mathrm{ab}$ & $86,67 \mathrm{~b}$ \\
$4 \%$ & $6,67 \mathrm{a}$ & $40,00 \mathrm{ab}$ & $70,00 \mathrm{ab}$ & $73,33 \mathrm{~b}$ & $83,33 \mathrm{ab}$ & $83,33 \mathrm{ab}$ & $90,00 \mathrm{ab}$ \\
$5 \%$ & $3,33 \mathrm{a}$ & $46,67 \mathrm{a}$ & $73,33 \mathrm{a}$ & $93,33 \mathrm{a}$ & $93,33 \mathrm{a}$ & $93,33 \mathrm{a}$ & $100 \mathrm{a}$ \\
\hline F-hitung & $1,71^{\text {tn }}$ & $17,79^{*}$ & $34,53^{*}$ & $91,1^{*}$ & $72,49^{*}$ & $29,85^{*}$ & $88,51^{*}$ \\
F-0,05 & 3,33 & 3,33 & 3,33 & 3,33 & 3,33 & 3,33 & 3,33 \\
F-0,01 & 5,64 & 5,64 & 5,64 & 5,64 & 5,64 & 5,64 & 5,64 \\
\hline BNT & 7,91 & 13,15 & 14,48 & 10,50 & 12,28 & 19,57 & 12,28 \\
\hline
\end{tabular}

Keterangan: $*$ nyata pada taraf $5 \%$, tn $=$ tidak nyata pada taraf $5 \%$ 
Selain itu, Daya racun juga dapa diduga melalui Lethal Time (LT) 50. Nilai LT50 ekstrak daun babadotan pada konsentrasi $1 \%$ adalah 33,30861 . Hal ini menunjukkan bahwa mortalitas larva 50\% dengan aplikasi ekstrak daun babadotan pada konsentrasi1\% akan terjadi pada 33,30861 jsa. Sedangkan pada konsentrasi tertinggi 5\% nilai LT50 adalah 10,85674 (Tabel 3). Hasil uji probit menunjukkan bahwa Nilai LT50 pada ekstrak daun babadotan LT50 semakin rendah dengan menigkatnya konsentrasi ekstrak daun babadotan. Hal ini mengakibatkan bahwa semakin tinggi konsentrasi, kemampuan membunuh semakin cepat.

Daun babadotan dapat diketahui memiki potensi dalam mempengaruhi P. xylostella berdasarkan tingkat konsentrasi yang digunakan serta lamanya waktu setelah aplikasi. Konsentrasi yang dibutuhkan untuk membunuh P. xylostella dalam suatu waktu sering kita kenal dengan LC50 yaitu kemampuan ekstrak daun babadotan untuk membunuh 50\% organisme (Hasibuan, 2012). Hasil nilai LC50 menunjukan semakin lama waktu semakin rendah nilai konsentrasi babadotan untuk membunuh atau mempengaruhi organisme yang diberikan sehingga membentuk kurva yang semakin menurun (Hasibuan, 2012) (Gambar 2).

Untuk mengetahui waktu yang dibutuhkan daun babadotan dalam membunuh atau mempengaruhi $P$. xylostella pada suatu konsentrasi sering menggunakan nilai LT50. Dari nilai LT50 tersebut dapat kita lihat bahwa semakin tinggi konsentrasi waktu yang dibutuhkan untuk membunuh atau mempengaruhi $P$. xylostella sangat cepat sehingga digambarkan kurva semakin menurun (Hasibuan, 2012) (Gambar 3.)

Pengaruh mortalitas pada daun babadotan terhadap $P$. xylostella dikarenakan adanya senyawa aktiv. Beberapa senyawa aktiv pada babadotan yaitu alkaloid, kumarin, tanin saponin, minyak atsiri dan flavonoid. Kandungan Alkaloid yang tinggi dapat menghambat pertumbuhan larva dan menurunkan daya tahan tubuh. Saponin berpengaruh terhadap mortalitas serangga karena dapat menyebabkan haemolisis pada sel darah merah serta melemahkan syaraf. Rusaknya sel-sel syaraf mengakibatkan nafsu makan menurun dan akhirnya tubuh serangga melemah dan mengalami kematian. Haemolisis pada sel darah merah pada sistem pernapasan dapat melumpuhkan syaraf pusat sehingga menganggu pernapasan dan berdampak pada kematian (Kinasih, 2013). Kandungan minyak atsiri pada babadotan yang dapat menghasilkan bau dan uap apabila terhirup terus melalui sistem pernapasan pada konsentrasi tinggi dapat mengakibatkan depresi pada syaraf sehingga menimbulkan kematian. Kandungan flavonoid bekerja dengan masuk melalui sistem pernafasan dan merusak bagian spirakel serta menimbulkan kelayuan pada syaraf yang mengakibatkan

Tabel 2. Hasil analisis probit Lethal Concentration(LC) 24 jam ekstrak daun babadotan terhadap Plutella xylostella

\begin{tabular}{cccc}
\hline \multirow{2}{*}{ Probablitas } & \multirow{2}{*}{ LC } & \multicolumn{2}{c}{ Taraf Kepercayaan 95\% } \\
\cline { 3 - 4 } & & Batas Bawah & Batas Atas \\
\hline 0,15 & 0,38673 & 0,15407 & 0,62897 \\
0,50 & 2,02539 & 1,59923 & 2,42805 \\
0,95 & 28,03776 & 15,37889 & 88,30625 \\
\hline
\end{tabular}

Tabel 3. Hasil analisis probit Lethal Time (LT) $50 \%$ dalam waktu 72 Jam

\begin{tabular}{cccc}
\hline \multirow{2}{*}{ Perlakuan (\%) } & \multirow{2}{*}{ LT 50 } & \multicolumn{2}{c}{ Taraf Kepercayaan 95\% } \\
\cline { 3 - 4 } & & Batas Bawah & Batas Atas \\
\hline 1 & 33,30861 & 30,10958 & 36,60705 \\
2 & 20,67922 & 13,60643 & 29,12665 \\
3 & 21,08384 & 17,84558 & 24,19049 \\
4 & 12,64822 & 10,17753 & 15,19672 \\
5 & 10,85674 & 6,41354 & 15,11917 \\
\hline
\end{tabular}




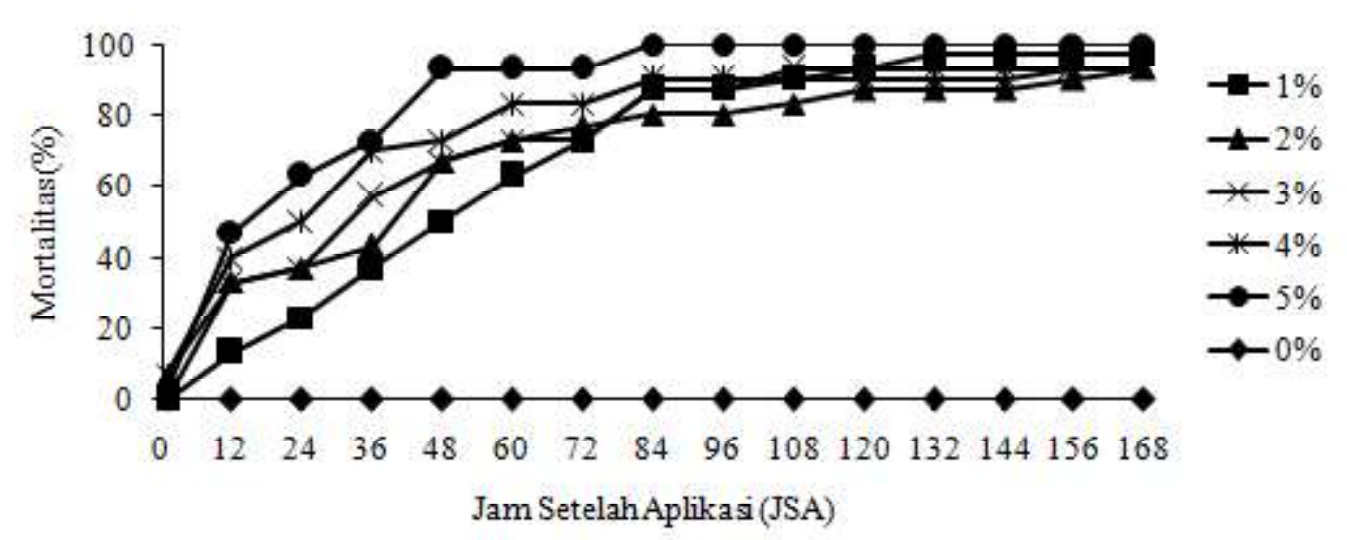

Gambar 1. Persentase mortalitas P. xylostella yang diaplikasi ekstrak daun babadotan (A. conyzoides) selama percobaan 168 jam.

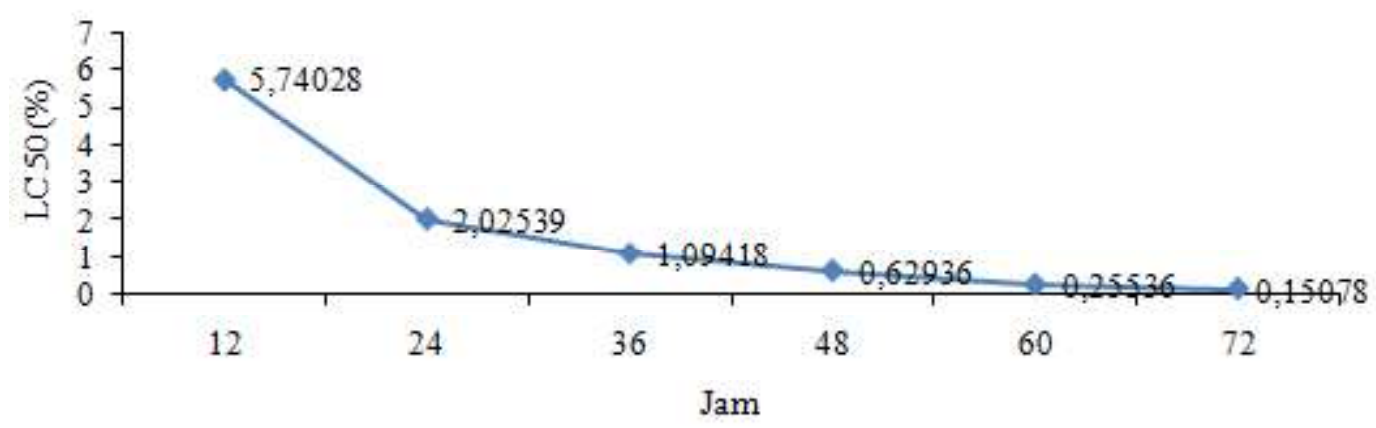

Gambar 2. Nilai Lethal Concentrat (LC) 50 Pada Beberapa Jam Setelah Aplikasi Ekstrak Daun Babadotan ( $A$. conyzoides) terhadap P. xylostella.

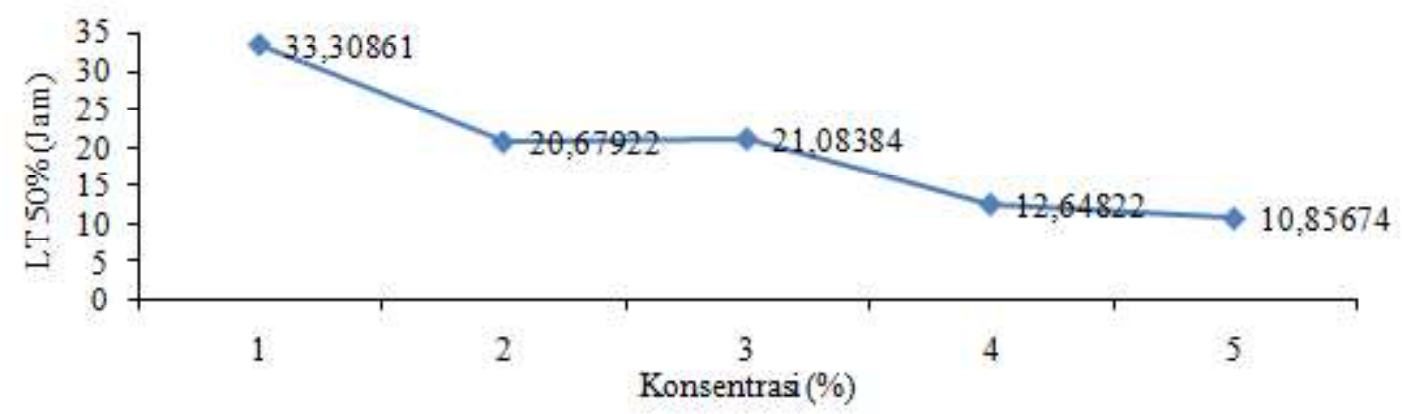

Gambar 3. Nilai Lethal Time (LT) 50 pada Konsentrasi Ekstrak Daun Babadotan (A. conyzoides) terhadap $P$. xylostella.

kematian pada serangga. Flavonoid apabila masuk ke sel darah akan berpengaruh terhadap syaraf sehingga menimbulkan depreis yang berujung kematian seperti pada penelitian perlakuan penyuntikan ekstrak daun babadotan kepada tikus (Ravinder dan Sarabjit, 2015)

Serangga Plutella xylostella yang cacat. Aplikasi ekstrak daun babadotan pada P. xylostella selain menimbulkan mortalitas juga mempengaruhi pertumbuhan dan perkembangan serangga uji. Perilaku P. xylostella setelah aplikasi dialami pada perubahan instar larva, pembentukan pupa dan pembentukan imago. Perilaku P.xylostella yang terjadi seperti kegagalan dan kecacatan dalam pebentukan pupa. Persentasi $P$. xylostella yang berhasil menjadi pupa dan kecacatanya disebutkan dalam Tabel 4.

Pada perlakuan konsentrasi 1\% mengalami pupa cacat sebanyak $20 \%$. Dengan kata lain, serangga uji yang diaplikasikan ekstrak daun babadotan pada keseluruhan konsentrasi 1\% memiliki persentase ratarata $20 \%$ pupa cacat. Pupa cacat pada konsentrasi $2 \%$ 
adalah 13\%, konsentrasi 3 adalah 17\%, konsentrasi 4\% adalah $3 \%$ dan konsentrasi $5 \%$ adalah $7 \%$. Untuk perlakuan kontrol (konsentrasi 0\%) persentasi pupa cacat tidak ada.

Pemberian ekstrak daun babadotan terhadap $P$. xylostella setelah aplikasi dapat menimbulkan terjadinya kegagalan dan kecacatan dalam pebentukan imago. Persentasi $P$. xylostella yang berhasil menjadi imago dan kecacatanya disebutkan dalam Tabel 5.

Pada perlakuan konsentrasi $1 \%, 2 \%$ dan 3\% mengalami imago cacat sebanyak 7\%. Dengan kata lain, serangga uji yang diaplikasikan ekstrak daun babadotan pada keseluruhan konsentrasi 1\%, 2\% dan 3\% memiliki persentase rata-rata $7 \%$ imago cacat. Imago cacat pada konsentrasi 4\% dan 5 adalah 3\%. Untuk perlakuan kontrol (konsentrasi $0 \%$ ) persentasi imago cacat tidak ada. Selain pengaruh mortalitas $P$. xylostella beberapa serangga mengalami gejala dan perilaku yang tidak normal (cacat) akibat senyawa aktiv pada daun babadotan. Gejala dan perilaku akibat senyawa aktiv daun babadotan pada larva yang tidak mati setelah diaplikasi yaitu lambat gerak, larva mengecil, warna integumen memucat menguning dan bagian ujung berwana hitam hingga keseluruh tubuh (Gambar 4).
Senyawa aktif pada daun babadotan tersebut atau sering disebut zat metabolit sekunder yang mampu membuat toksik pada beberapa serangga. Komponen utama pada metabolit sekunder yaitu senyawa Prococene I dan Prococene II (Ditjenbun, 1994). Prococene merupakan turunan dari senyawa asetat dan lima atom karbon lainya yang merupakan bagian dari senyawa terpenoid. Prococene yang terdapat didalam daun babadotan memiliki sifat antifeedant terhadap beberapa serangga sehingga dapat bekerja secara kontak dan racun perut (Christiyanto, 2013). Senyawa Prococene II ketika masuk melalui sistem pencernaan dapat mereduksi secara signifikan pada kecepatan pertumbuhan, kecepatan asimilasi nutrisi dan mengakibatkan tubuh menjadi ringan sehingga larva terlihat mengecil. Larva yang berwarna hitam atau terlihat gosong dari ujung dan lama kelamaan keseluruh tubuh dikareakan rusaknya kutikula (Gambar 4). Racun yang langsung bersentuhan dengan kutikula larva $P$. xylostella dapat langsung teracuni karena larutan ekstrak babadotan tersebut bersifat apolar sehingga mudah menembus dan meresap melalui kutikula dan akhirnya menyebar keseluruh bagian tubuh (Hasibuan, 2012).

Tabel 4. Persentase jumlah P. xylostella yang membentuk pupa normal dan cacat

\begin{tabular}{cccc}
\hline \multirow{2}{*}{ Perlakuan \%) } & \multicolumn{2}{c}{ Pupa } & Total (\%) \\
\cline { 2 - 3 } & Normal (\%) & Cacat (\%) & 100 \\
\hline 0 & 100 & 0 & 33 \\
2 & 13 & 20 & 20 \\
3 & 7 & 13 & 23 \\
4 & 7 & 17 & 10 \\
5 & 7 & 3 & 7 \\
\hline
\end{tabular}

Tabel 5. Persentase Plutella xylostella yang membentuk imago normal dan cacat

\begin{tabular}{cccc}
\hline \multirow{2}{*}{ Perlakuan (\%) } & \multicolumn{2}{c}{ Imago } & Total (\%) \\
\cline { 2 - 4 } & Normal (\%) & Cacat (\%) & 100 \\
1 & 100 & 0 & 20 \\
2 & 13 & 7 & 14 \\
3 & 7 & 7 & 17 \\
4 & 10 & 7 & 10 \\
5 & 7 & 3 & 7 \\
\hline
\end{tabular}




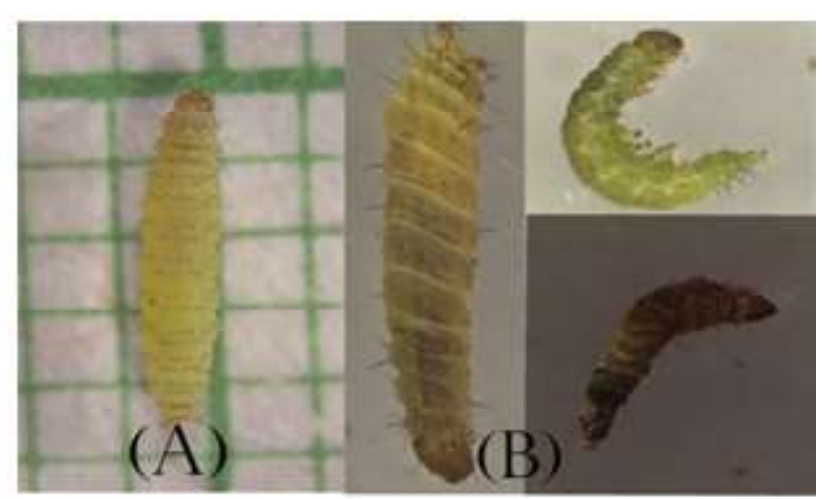

Gambar 4. Larva P. xylostella (A) Larva sehat (B) Larva cacat/mati.

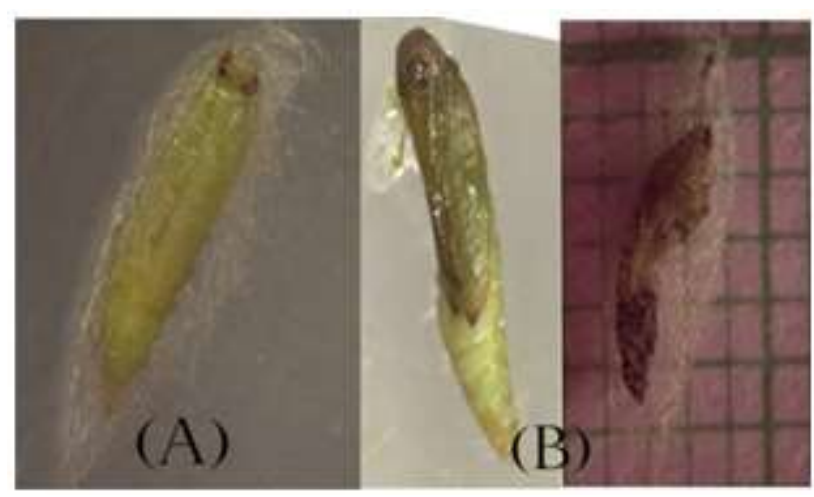

Gambar 5. Pupa P. xylostella (A) Pupa sehat (B) Pupa cacat/mati.

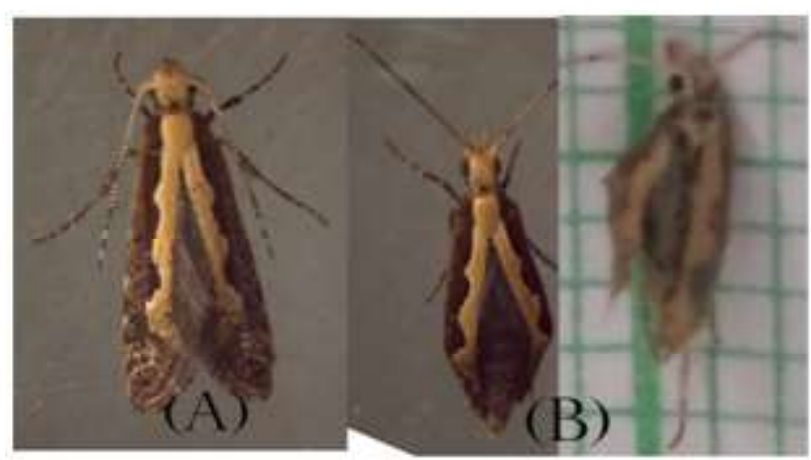

Gambar 6. Imago P. xylostella (A) Imago normal (B) Imago cacat.

Kegagalan dalam pembentukan atau kematian pupa tidak luput akibat imbas dari perlakuan konsentrasi ekstrak daun babadotan. Pembentukan pupa tidak lepas dari bantuan hormon yang ada pada tubuh serangga itu sendiri. Hormon utama yang digunakan dalam perkembangan yaitu hormon ekdison dan hormon juvenil. Hormon ekdison dibutuhkan ketika adanya pergantian kulit dan apabila terlalu tinggi akan mempercepat prosesnya sedangkan hormon juvenil dibutuhkan untuk mempertahankan bentuk serangga. Kecacatan pupa dapat disebabkan karena tubuh serangga pada corpora allata tidak mampu memproduksi hormon juvenil secara stabil. Rusaknya corpora allata karena mengalami nekrosis dan atropi yang disebabkan senyawa Prococene akibat anti terhadap hormon juvenil. Rendahnya produksi Hormon juvenil memicu PTTH (Prothoracicotropic Hormone) untuk menstimulasi kelenjar protoraks menghasilkan hormon ekdison akibatnya pergantian kulit atau proses pemupaan dipercepat dan menghasilkan pupa tidak sempurna (cacat). Terjadinya kematian pada pupa dapat disebabkan karena kurangnya cadangan makanan dan belum siapnya serangga menjadi pupa.

Hasil penelitian P. xylostella beberapa imago mengalami tidak normal (cacat) (Gambar 6.). Kecacatan imago dikarenakan senyawa Prococene yang mengakibatkan tidak stabilnya hormon didalam tubuh serangga. Prococene juga dapat mengakibatkan otototot dan bagian sayap tidak sempurna.

\section{KESIMPULAN}

Berdasarkan uji potensi daun babadotan (Ageratum conyzoides) terhadap Plutella xylostella disimpulkan bahwa pada konsentrasi 1-5\% ekstrak daun babadotan (A. conyzoides) menimbulkan mortalitas dan penghambatan pertumbuhan P. xylostella. Aplikasi ekstrak daun babadotan pada pengamatan 24 jam setelah aplikasi memiliki daya bunuh $50 \%$ serangga uji (LC50) pada konsentrasi 2,02539\%. Aplikasi ekstrak daun babadotan juga memiliki kecepatan membunuh 50\% serangga uji (LT50) pada 33,31 Jam untuk perlakuan konsentrasi $1 \%, 20,68$ jam untuk $2 \%, 21,09$ jam untuk $3 \%, 12,65$ jam untuk $4 \%$ dan 10,86 jam untuk $5 \%$.

\section{DAFTAR PUSTAKA}

Andi, S. 2007. Efikasi Ekstrak Babandotan (Ageratum conizoydes L.) terhadap Crocidolomia binotalis Zeller. Skripsi. Universitas Bengkulu. $56 \mathrm{hlm}$.

Astriani, D. 2010. Pemanfaatan Gulma Babadotan dan Tembelekan Dalam Pengendalian Sitophilus spp. pada Benih Jagung. Jurnal Agrisains.Vol.1(1) : 56-67.

Cahyono, B. 1995. Cara Meningkatkan Budidaya Kubis. Yayasan Pustaka Nusantara. Yogyakarta. $86 \mathrm{hlm}$.

Christiyanto, J. 2013. Toksisitas Ekstrak Daun Babadotan (Ageratum conyzoides L.) terhadap Ulat Grayak (Spodoptera litura F.) di 
Laboratorium. Skripsi. Universitas Lampung. Bandar Lampung. $21 \mathrm{hlm}$.

Grainge, M. dan S. Ahmed. 1988. Handbook of Plants with Pest-Control Properties. John Wiley \& Sons. Inc. Canada. $470 \mathrm{hlm}$.

Hasibuan, R. 2012. Insektisida Pertanian. Lembaga Penelitian Universitas Lampung. Bandar Lampung, $149 \mathrm{hlm}$.

Kinasih, I. 2013. Uji Toksisitas Ekstrak Daun Babadotan (Ageratum conyzoides Linn) terhadap Ikan Mas (Cyprinus carpio Linn.) sebagai Organisme Non-Target. Jurnal Jurusan Biologi Fakultas
Sains dan Teknologi UIN Sunan Gunung Djati Bandung. 7(2) : 121-132.

Ravinder Kaur dan Sarabjit Kaur, 2015. Anxiolytic Potential of Methanol Extract form Ageratum conyzoides Linn Leaves. PHCOG J. 7 (4) : 236241.

Tenrirawe, 2011. Pengaruh Ekstrak Daun Sirsak Annona Muricata L. terhadap Mortalitas Larva Helicoverpa Armigera $\mathrm{H}$ pada Tanaman Jagung. Seminar Nasional Serealia Maros. Balai Tanaman Serealia Maros. 521-529 